Louisiana State University

LSU Digital Commons

Faculty Publications

Department of Biological Sciences

$9-1-2016$

\title{
Phragmites australis as a model organism for studying plant invasions
}

Laura A. Meyerson

University of Rhode Island

James T. Cronin

Louisiana State University

Petr Pyšek

Institute of Botany of the Academy of Sciences of the Czech Republic

Follow this and additional works at: https://digitalcommons.Isu.edu/biosci_pubs

\section{Recommended Citation}

Meyerson, L., Cronin, J., \& Pyšek, P. (2016). Phragmites australis as a model organism for studying plant invasions. Biological Invasions, 18 (9), 2421-2431. https://doi.org/10.1007/s10530-016-1132-3

This Article is brought to you for free and open access by the Department of Biological Sciences at LSU Digital Commons. It has been accepted for inclusion in Faculty Publications by an authorized administrator of LSU Digital Commons. For more information, please contact ir@lsu.edu. 


\title{
Phragmites australis as a model organism for studying plant invasions
}

\author{
Laura A. Meyerson (1D) James T. Cronin · Petr Pyšek
}

Received: 18 December 2015/Accepted: 24 March 2016/Published online: 26 April 2016

(C) Springer International Publishing Switzerland 2016

\begin{abstract}
The cosmopolitan reed grass Phragmites australis (Poaceae) is an intensively studied species globally with a substantial focus in the last two decades on its invasive populations. Here we argue that $P$. australis meets the criteria to serve as a model organism for studying plant invasions. First, as a dominant species in globally important wetland habitats, it has generated significant pre-existing research, demonstrating a high potential for funding. Second, this plant is easy to grow and use in experiments.
\end{abstract}

Guest editors: Laura A. Meyerson and Kristin Saltonstall/ Phragmites invasion.

L. A. Meyerson ( $\square)$

The University of Rhode Island, Kingston, RI 02881, USA

e-mail: lameyerson@gmail.com

J. T. Cronin

Louisiana State University, Baton Rouge, LA 70803, USA

P. Pyšek

Institute of Botany, The Czech Academy of Sciences,

Zámek 1, 25243 Průhonice, Czech Republic

P. Pyšek

Department of Ecology, Faculty of Science, Charles University in Prague, Viničná 7, 12844 Prague, Czech Republic

P. Pyšek

Centre for Invasion Biology, University of Stellenbosch, Matieland 7602, South Africa
Third, it grows abundantly in a wide range of ecological systems and plant communities, allowing a broad range of research questions to be addressed. We formalize the designation of $P$. australis as a model organism for plant invasions in order to encourage and standardize collaborative research on multiple spatial scales that will help to integrate studies on the ecology and evolution of $P$. australis invasive populations, their response to global environmental change, and implications for biological security. Such an integrative framework can serve as guidance for studying invasive plant species at the population level and global spatial scale.

Keywords Genome size - Global climate change · Global research network · Herbivory · Hybridization . Ploidy level

\section{Introduction}

Phragmites australis (Cav.) Trin. ex Steud. (formerly $P$. communis, common reed, Poaceae family) has been mentioned as a model organism for plant invasions by a number of researchers because of its near global distribution (Clevering and Lissner 1999), well-known invasion history in North America (Saltonstall 2002), ease of detection using aerial or satellite imagery (Bhattarai and Cronin 2014), high genetic and karyological diversity (Meyerson et al. 2016), occurrence as multiple lineages and genotypes along latitudinal or 
climatic gradients (Cronin et al. 2015; Hughes et al. 2016), and for its array of traits that are easily measured and highly variable depending on genotype and/or environmental conditions (e.g., Meyerson et al. 2000a, b; Achenbach et al. 2013; Mozdzer et al. 2013; Guo et al. 2013). Here we formalize the recognition of $P$. australis as a model organism for plant invasions by adapting the criteria outlined by Kueffer et al. (2013) who suggested that using model systems in invasion science could facilitate and strengthen global collaboration and allow investigators to address fundamental questions in invasion science through integrative research.

The use of model organisms in plant research, such as Arabidopsis thaliana, is well established and highly valued because a useful model organism is easily manipulated, genetically tractable, and about which much is already known, thus allowing researchers to rapidly accumulate comprehensive knowledge of the whole plant. Model plant species allow researchers to test hypotheses quickly and efficiently thereby functioning as a reference system for other plant systems and more quickly advancing empirical science-a particularly important undertaking for invasion ecology and research that seeks to predict the effects of global change. Our interpretation of a model species follows that of Kueffer et al. (2013), who suggested that invasion science can profit from in-depth research of invasions of particular taxa ('model organisms') or at a particular site ('model ecosystems'), and from the integration of diverse information on such taxa or sites. Developing model systems in invasion science has become increasingly possible due to recent accumulation of comprehensive datasets on selected invasive species and research focused on particular model systems will help to identify processes relevant for understanding invasions, and identifying their underlying mechanisms

Kueffer et al. (2013) adapted the following criteria for identifying model organisms in invasion science: a model organism should (1) be characterized by the existence of substantial pre-existing research, tools and knowledge; (2) readily lend itself to research and use in experiments; (3) represent a wide range of systems and species; and (4) facilitate high versatility for research and funding. We assert that $P$. australis readily meets all these criteria and we provide evidence to support each point below. This is not meant to be an exhaustive review of the published literature on $P$. australis. Instead, it is meant to be a concise argument, with key examples, for why $P$. australis makes is a good model species.

\section{Substantial research, tools and knowledge exist for Phragmites australis}

Phragmites australis is arguably among the world's most studied plants and is cited by Pyšek et al. (2008) as the third most studied plant species over the period 1980-2006 and by Hulme et al. (2013) as being among the five most studied invasive species globally. There is a wealth of information on its ecophysology and population dynamics from the native European range where it has been subject of intensive research effort and international projects since 1970s (Dykyjová et al. 1973; Tscharntke 1992; Č́ž́ková et al. 1996; Brix 1999). Its introduction and invasion history is relatively well known, especially in North America (Chambers et al. 1999; Saltonstall 2002). Numerous recent reviews have synthesized the ecology, evolution, management (Hazelton et al. 2014), costs (Martin and Blossey 2013), and benefits (Kiviat 2013) of this species. The Web of Science database yielded 4142 published papers for the search term "Phragmites" and 3503 for Phragmites australis as the "topic" from 1950 to 2016 (Fig. 1). More generally, Google Scholar returned $>25,000$ hits for the search term "Phragmites australis" indicating a broad exchange of knowledge through news outlets, management and academic literature.

One strong argument for $P$. australis to qualify as a suitable model species is that this plant is researched by an order of magnitude more intensively than other notorious plant invaders and candidate model species (Table 1). Although not all the information that is available refers to its invasion, the research so far has accumulated a solid knowledge base from a variety of disciplines. A brief inspection of the 1033 case studies returned by the WoS search reveals that in addition to the most represented research areas such as environmental sciences, ecology and conservation (43\%), plants sciences (36\% of all papers), and marine and freshwater biology (28\%) are well represented. More practically oriented fields like engineering $(9 \%)$, agriculture $(6 \%)$, microbiology and biotechnology $(6 \%)$ or research in water resources $(5 \%)$ 


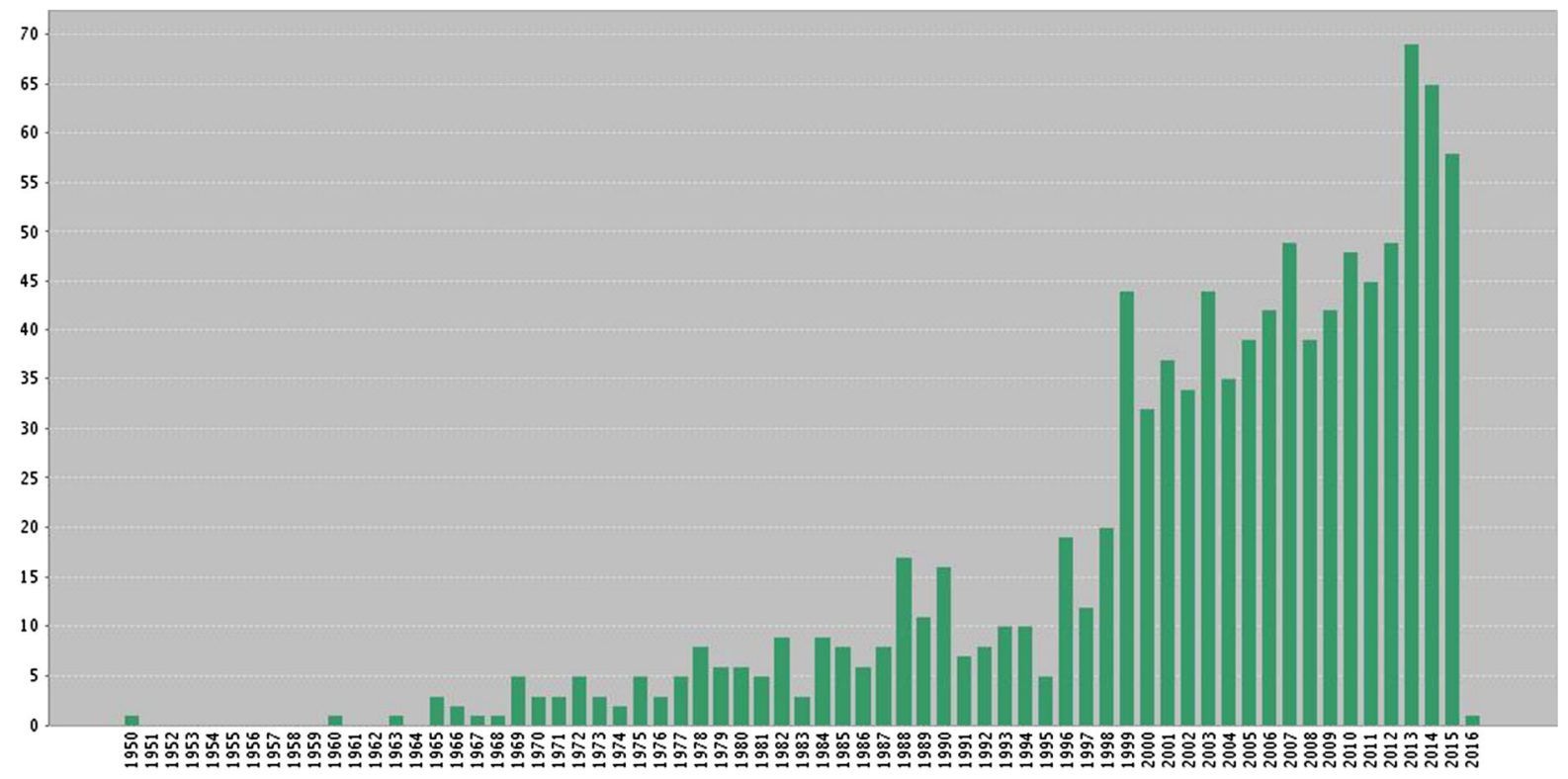

Fig. 1 Number of publications over time for journal articles with Phragmites australis as the main research topic, as indicated by the species name used in the paper title

are also a part of the literature on $P$. australis. Another feature that makes $P$. australis a strong candidate for a model species is that it is represented on all continents except Antarctica, and both native and invasive populations have very broad geographic ranges. Other prospective model invasive species listed in the Table 1 are geographically limited in one way or another, making them rather difficult, if not impossible, to use to address questions related to global macroecological patterns or, e.g., global change.

Phragmites australis is an easily recognizable plant species whose lineages and subspecies in North America can often be distinguished based on morphology but sometimes require genetic confirmation. The genetic and morphological tools to rapidly identify the origin and genotypes of $P$. australis were published by Saltonstall (2002, 2003a, b), Saltonstall et al. (2004). These tools led to a rapid and exponential increase in the possibilities for research on this species, resulting in an ever increasing body of work by researchers from around the globe working to identify lineages, subspecies, haplotypes (Saltonstall 2003a, b; Saltonstall et al. 2004; Meyerson and Cronin 2013), and hybrids of $P$. australis (Saltonstall et al. 2016, this issue; Lambertini et al. 2012; Lambert et al.
( $\mathrm{n}=1019$, Web of Science Core Collection, Title: Phragmites australis OR Phragmites communis, 18 December 2015)

2016, this issue; Meyerson et al. 2010a, b, 2012). More recently, the full plastid genome of $P$. australis has been published on the NCBI website (http://www. ncbi.nlm.nih.gov/bioproject/174737).

The great research intensity makes $P$. australis rather exceptional among invasive species in that there is a large body of literature from its native range (e.g. Brix 1999). As shown recently in a thorough comparison of 26 plant species considered among the world worst invaders, data from native ranges are generally rather scarce (Parker et al. 2013). Phragmites australis is widely studied in both its native and introduced ranges for its ability to rapidly colonize new areas (Chambers et al. 1999) and efficiently uptake nutrients (Brix 1994; Meyerson et al. 1999, 2000a, b). Comparisons of native and invasive populations have also been made with regard to genetic and karyological diversity (Clevering and Lissner 1999; Saltonstall 2002; Lambertini et al. 2006, 2012; Meyerson et al. 2016, this issue), wildlife habitat (Kiviat 2013), competitive ability (Holdredge et al. 2010), trophic interactions (Tscharntke 1992; Cronin et al. 2015; Allen et al. 2015; Hughes et al. 2016; Bhattarai et al. in review) and many other factors that may be related to this species' invasiveness. 
Table 1 Comparison of Phragmites australis with some of other world's major invasive plant species, for the major criteria that make a species a suitable model organism (see text for details)

\begin{tabular}{|c|c|c|c|c|c|}
\hline Species & Life history & $\begin{array}{l}\text { Pre-existing } \\
\text { research }\end{array}$ & $\begin{array}{l}\text { Size of } \\
\text { the native } \\
\text { range }\end{array}$ & $\begin{array}{l}\text { Size of the } \\
\text { invaded } \\
\text { range }\end{array}$ & Invaded habitats \\
\hline $\begin{array}{l}\text { Phragmites australis } \\
\quad \text { (Poaceae) }\end{array}$ & Perennial grass & 1033 & 7 & 9 & $\begin{array}{l}\text { Freshwater wetland, riparian } \\
\text { habitats, coastal marshes, } \\
\text { disturbed sites }\end{array}$ \\
\hline $\begin{array}{l}\text { Typha latifolia } \\
\text { (Poaceae) }\end{array}$ & Perennial grass & 265 & 14 & 6 & $\begin{array}{l}\text { Freshwater wetland, marhes, } \\
\text { coastal estuaries }\end{array}$ \\
\hline $\begin{array}{l}\text { Phalaris arundinacea } \\
\text { (Poaceae) }\end{array}$ & Perennial grass & 210 & 8 & 13 & $\begin{array}{l}\text { Forests, freshwater wetland, } \\
\text { riparian habitats }\end{array}$ \\
\hline $\begin{array}{l}\text { Bromus tectorum } \\
\quad \text { (Poaceae) }\end{array}$ & Annual grass & 268 & 9 & 4 & Grassland, scrubland, rangeland \\
\hline $\begin{array}{l}\text { Fallopia japonica } \\
\text { (Polygonaceae) }\end{array}$ & $\begin{array}{l}\text { Polycarpic perennial } \\
\text { herb }\end{array}$ & 86 & 1 & 4 & $\begin{array}{l}\text { Woodland, forest edges, riparian } \\
\text { habitats, wetlands, disturbed sites }\end{array}$ \\
\hline $\begin{array}{l}\text { Heracleum } \\
\text { mantegazzianum } \\
\text { (Apiaceae) }\end{array}$ & $\begin{array}{l}\text { Monocarpic } \\
\text { perennial herb }\end{array}$ & 67 & 1 & 8 & $\begin{array}{l}\text { Riparian habitats, grassland, forest } \\
\text { edges, disturbed sites }\end{array}$ \\
\hline $\begin{array}{l}\text { Alliaria petiolata } \\
\text { (Brassicaceae) }\end{array}$ & Annual herb & 122 & 9 & 3 & $\begin{array}{l}\text { Forests and forest edges, grassland, } \\
\text { riparian habitats }\end{array}$ \\
\hline $\begin{array}{l}\text { Centaurea stobe } \\
\text { (Asteraceae) }\end{array}$ & Polycarpic perennial & 47 & 4 & 5 & $\begin{array}{l}\text { Grassland, riparian habitats, } \\
\text { rangeland, woodland }\end{array}$ \\
\hline
\end{tabular}

WoS Core Collection search was used as a measure of research intensity (as of 27 February 2016); by restricting the search criterion to the plant name in the title of the paper this search refers to case studies rather than to any mention about the species. The most common synonyms were also included in the search (i.e. Phragmites communis, Baldingera arundinacea, Reynoutria japonica, and Alliaria officinalis). Size of the native and invaded range is expressed as the number of regions $(\mathrm{n}=32)$ as given by Weber $(2003)$, in which the species is native or naturalized, respectively

Although the information about the number of invaded versus native regions may be outdated in this data source, not reflecting the last decade of research, it is kept here for comparative purpose. Invaded habitats are taken from Weber (2003) and updated for $P$. australis

\section{Phragmites australis is easy to research and use in experiments}

\section{Primary research}

Phragmites australis is highly adaptable and can grow in a range of ecosystems including coastal marshes, inland lakes and rivers, mountains, deserts and urban areas (Packer et al. 2016). It is readily identified using both aerial photographs, including historic images (Bhattarai and Cronin 2014), LiDAR and satellite imagery (Gilmore et al. 2008). Consequently, $P$. australis is ideally suited for remote sensing and landscape-level studies. Because different lineages (Swearingen and Saltonstall 2010) and hybrids (Lambertini et al. 2012) can have distinct morphological and color traits, they are also distinguishable in the field.
Phragmites australis is readily propagated by seed, rhizome or stem node (Haslam 1971a, b; Meyerson et al. 2014) for greenhouse, common garden or growth chamber experiments and can be grown in a variety of substrates including field soils and commercial sand and soil mixes. While some populations are hardier than others, $P$. australis tolerates a wide range of winter and summer temperatures and is therefore amenable to use in multiple common gardens across a wide range of latitudes and climates (Bhattarai et al. in review). Phragmites australis is also relatively easy to find growing wildly in places where there is adequate moisture. Multiple genotypes and lineages of $P$. australis grow sympatrically in Europe, Asia and North America (Saltonstall 2002; Lambertini et al. 2012; Lambert et al. 2016, this issue; Meyerson and Cronin 2013; Meyerson et al. 2009; Cronin et al. 
2015) and there are increasing reports of wild hybrids (Wu et al. 2015; Saltonstall et al. 2014; Saltonstall et al. 2016, this issue; Lambertini et al. 2012; Lambert et al. 2016, this issue). Additionally, $P$. australis can be easily interbred by hand within and between lineages (Meyerson et al. 2010a, b) or hybridized with other Phragmites species (C. Lambertini, unpublished data).

Furthermore, given the advantages described above (significant amount of available data from genetic to ecosystem level, high genetic and karyological diversity, easy to use, globally distributed, etc.), $P$. australis is a logical choice for experimental tests of ecological theory in plant invasions. For example, Cronin et al. (2015) and Allen et al. (2015) found support for the enemy release hypothesis (ERH) because levels of herbivory were significantly lower on the introduced genotype in North America than on the same genotype in the native European range. Interestingly, there was no evidence that release from natural enemies resulted in the evolution of reduced defenses in the invaded range that would support the evolution of increased competitive ability (EICA) hypothesis (Blossey and Nötzold 1995). In addition, the complex interactions between $P$. australis and its herbivores, including multiple species of introduced stem-galling moths (Lipara) from Europe, suggest that an invasional meltdown (Simberloff and Von Holle 1999) may be underway in North America. Predicting potential niche shifts by invasive species in their introduced ranges is widely recognized as critically important to assessing the establishment and spread of invaders (Broennimann et al. 2007). Using environmental niche models for data on two lineages of $P$. australis in their native and introduced ranges, Guo et al. (2013) found evidence for a niche shift in two lineages due to recent changes in precipitation and temperature and suggested that ongoing human disturbance will continue to alter niches in the native and introduced ranges.

Management and ecosystem restoration

Restoration of degraded ecosystems has been described as the "acid test" of ecological knowledge (Egan 2001) making management efforts to remove invasive plants and restore native communities both a practical matter and a research opportunity. A number of studies have shown that the negative effects of invasive $P$. australis are reversible for some plant, fish and insect communities (Farnsworth and Meyerson 1999; Able et al. 2003; Gratton and Denno 2006; Hunter et al. 2006; Dibble et al. 2013; Dibble and Meyerson 2012, 2013, 2016, this issue). Many restoration and management efforts for $P$. australis have used mechanical and chemical approaches and have been long-term and large-scale (Marks et al. 1994; Hazelton et al. 2014), yielding a wealth of information. Arthropod biological control agents for invasive $P$. australis genotypes have been considered but a growing body of ecological and evolutionary literature suggests that introductions of these species would be potentially catastrophic to existing native $P$. australis genotypes (Cronin et al. 2016, this issue). At the same time, new management tactics using soil microbes are being explored (see below). Therefore, using $P$. australis as a model system for invasive plant management associated with restoration offers opportunities to improve design, implementation and assessment on the ground. Assessments that include economic costs over time (Chambers et al. 1999; Martin and Blossey 2013; Hazelton et al. 2014) and empirical evidence of restoration outcomes across trophic levels may ultimately assist in prioritization of restoration efforts, better monitoring and ecologicalindicator development.

\section{Phragmites australis occurs in a wide range of ecosystems with diverse food webs}

\section{Habitats and biogeography}

The thousands of published research papers on $P$. australis across many ecosystem types and continents (Fig. 1) and the restoration efforts aimed at managing its stands clearly establish this species as representative in natural, managed and urban systems. It is especially amenable to diverse types of research from both scientific and management-focused agencies. Below we provide examples of published research and management efforts in order to demonstrate future potential.

Phragmites australis and its associated fauna and flora represent a wide range of habitats with diverse biological communities across continents and have been studied in detail for decades (Haslam 1971a, b). 
For example, in North America three different lineages of $P$. australis (sensu Saltonstall 2002) colonize both coastal tidal freshwater and brackish systems (Meyerson et al. 2000a, b), and are also found inland inhabiting ponds, lakes and rivers, inland freshwater marshes (even in desert systems; Lambert et al. 2016, this issue), at both high and low elevations (Packer et al. 2016), urban, suburban and other highly disturbed ecosystems such as roadsides, along railway corridors and other "waste places."

Increasingly, biogeographic approaches at large spatial scales are being applied to invasion research (Colautti et al. 2014), and this trend is also obvious for P. australis. For example, Cronin et al. (2015) studied populations of $P$. australis in its native range in Europe (from Norway to Portugal) and both introduced and native populations in North America (from New Brunswick to Florida) across more than 19 degrees of latitude on each continent. Comparing the native and introduced lineages in North America, they found non-parallel gradients in herbivory that suggests the strength of enemy release varies with latitude. Such a result would not have been detected at a more restricted spatial scale. Similarly, Bhattarai et al. (in review) used two common gardens representing a 17-degree latitudinal spread to test whether latitudinal clines in plant defense, palatability, and plasticity could be detected across different $P$. australis genotypes. They found latitudinal clines to be common for many traits and for more than a third of those traits, clines were non-parallel for the native and introduced genotypes, supporting the earlier findings of Cronin et al. (2015) and suggesting evolution of the introduced genotype in the novel environment over a short time scale $(<200$ years). Bhattarai et al. (in review) also found that invasive genotypes were more plastic than native genotypes and that plasticity for native genotypes increased with decreasing latitude. In the Czech Republic, Bastlová et al. (2006) conducted a common garden study using populations from six European countries and found an inverse relationship between latitude and P. australis traits (e.g., height, biomass) except for SLA, which had a positive relationship with latitude.

There are other globally or widely distributed largestatured invasive grasses such as Arundo donax (Lambert et al. 2010), Miscanthus spp., and many bamboo species (Canavan et al. 2016) that are ecologically, agriculturally, economically, and culturally important. Like $P$. australis, these grasses provide both ecosystem services such as water purification, erosion control, biofuels, and construction materials (Kiviat 2013) and present management challenges where they are considered invasive or weedy (Hazelton et al. 2014). The significant research and management data and future studies on $P$. australis should greatly inform the management of these and other pervasive large-statured invasive grasses.

Genetic, karyological, and epigenetic diversity

The seminal series of papers on the genetics of $P$. australis by Saltonstall $(2002,2003 \mathrm{a}, \mathrm{b})$ helped to usher in the ability of researchers to use this species for studies on the role of intraspecific genotypes in invasions, evolution, hybridization, as well as the interactions of genetics and the environment. Ploidy level in P. australis has been widely reported (e.g., Clevering and Lissner 1999; Pellegrin and Hauber 1999; Saltonstall et al. 2007) but no significant differences in genome size between native and introduced $P$. australis in North America were detected (Saltonstall et al. 2007). More recently, this work has extended to detailed global studies of $P$. australis genome size and ploidy levels which show significant differences between native and introduced lineages (Suda et al. 2014; Meyerson et al. 2016, this issue). Because $P$. australis is relatively easy to hybridize under controlled conditions (Meyerson et al. 2010a, b), studies of intraspecific genetic and genomic heritability (that also control for phylogenetic relationships) and the relationships of genotype, genome size and ploidy level to plant traits and species interactions (such as herbivory, e.g., Cronin et al. 2015; Allen et al. 2015; Meyerson et al. 2016, this issue) can be undertaken in the laboratory, common garden and field. Additionally, because high intraspecific genetic diversity, including hybrids, can be found in the wild, simultaneous field and garden studies can be designed to disentangle the relative contributions of genetics, the environment and species interactions to plant success, trait expression and ecosystem effects of invasion. The influence of epigenetics on plant invasions is increasingly being explored for invasive species (e.g., Prentis et al. 2013; Bossdorf et al. 2008) and P. australis offers the 
opportunity to explore epigenetics in the context of other genetic and genomic traits (see Douhovnikoff and Spens 2016, this issue).

\section{Microbial diversity}

Increasingly, invasion research is focusing on the fungal and bacterial communities that may be facilitating or hindering plant invasions. For P. australis, microbial communities are being studied in earnest, especially because of the opportunity to conduct research that compares genotypic and intraspecific difference from populations that grow sympatrically in the wild. For example, studies in North America comparing native and invasive $P$. australis genotypes found that soils of both were dominated by the oomycete Pythium, sp. but differed in species diversity and abundance (Nelson and Karp 2013). Some microbial taxa may more negatively impact native than invasive P. australis in North America (Crocker et al. 2015). Interesting new work on fungal endophytes indicates that reducing beneficial and increasing harmful fungal endophytes in invasive $P$. australis could eventually result in a novel method to control $P$. australis invasions (Kowalski et al. 2015; Clay et al. 2016, this issue; Soares et al. 2016, this issue).

Phragmites australis has also been shown to be facultatively mycorrhizal (Oliveira et al. 2001), supporting arbuscular mycorrhizal fungi (AMF, Harley and Harley 1987), but lacking ectomycorrhizal fungi (Oliveira et al. 2001). AMF colonization is thought to benefit $P$. australis by shortening germination length, increasing seedling growth rates, aiding nutrient uptake (Wu et al. 2014), and reducing stressful environmental conditions (Al-Garni 2006; Wu et al. 2014; Zhang et al. 2014).

Archaeal and bacterial communities among different $P$. australis genotypes have received less attention. Yarwood et al. (2016, this issue) sampled four sites on the Choptank River in the Chesapeake Bay, USA that included both the native and introduced genotypes of $P$. australis. They found that while bacterial biomass and composition did not significantly differ between genotypes, the archeael community composition and the number of copies of the 16s rRNA gene did differ significantly. Using phospholipid fatty acid profiles, they also found differences between bacterial lipids in the native and introduced genotypes suggesting differences in the sulphate reducing communities present. Another study in a common garden using populations from the northeast, mid-Atlantic and Gulf Coast, Bowen and Meyerson (unpublished data) found reduced diversity of the active bacterial community in the North American native genotype relative to the introduced genotypes reared under identical conditions. They also found that under the same conditions, native and introduced genotypes differed in plant and soil chemistry that ultimately resulted in reduced diversity among the active bacteria in native genotypes relative to invasive genotypes.

Global change studies

Phragmites australis has proven to be a highly useful species for studying the effects of global change on vegetation. For example, Caplan et al. (2014) showed a positive relationship between nitrogen availability, length of the growing season and net primary production for the introduced lineage in North America. Similarly, in a growth chamber experiment, Mozdzer and Megonigal (2013) found that under elevated $\mathrm{CO}_{2}$ and $\mathrm{N}$, both native and introduced $P$. australis in North America demonstrated higher $\mathrm{CH}_{4}$ emissions but overall those from the introduced genotypes were higher. They concluded that increased productivity, such as when an invasive plant replaces native communities, is likely associated with increased $\mathrm{CH}_{4}$ emissions. Salinity stress due to increased drought and sea level rise is another expected effect of global change. Eller et al. (2014) studied the European and Mediterranean genotypes of $P$. australis and suggested that for $\mathrm{C} 3$ species, global climate change may mitigate salinity stress and facilitate invasion.

\section{Research and funding}

In the US, more than $\$ 120$ billion USD are spent annually on managing invasive species with much of the spending occurring in the agricultural sector (Pimentel et al. 2005). Phragmites australis is an alternative summer host for the invasive aphid Hyalopterus pruni that is a pest of Prunus species in orchards (e.g., plums, cherrys, almonds, apricots; Lozier et al. 2009). Hyalopterus pruni can vector plant viruses such as plum pox virus (Isac et al. 1998). Also, various species of rusts, smuts and rots that attack $P$. australis are closely related and may be 
shared with various agricultural crops. Because $P$. australis may negatively impact these orchard and agricultural crops indirectly through their shared natural enemies (i.e., apparent competition; Holt and Lawton 1994), there is agricultural interest in this species.

While funding amounts can be notoriously difficult to track down, a search of the US National Science Foundation database using the search term Phragmites australis 12/16/2015 indicates more than two million dollars in funding to date for research related to $P$. australis. Martin and Blossey (2013) conducted a survey of 285 land managers in the US to ascertain economic costs associated with management and control of $P$. australis. Their results showed that between 2005 and 2009, more than \$4 million per year was spent on $P$. australis management. Although controversial (Cronin et al. 2016, this issue), funding for screening of biological control agents to manage $P$. australis is also available. Recently, a request for proposals (RFP Number: C-15-07) for up to $\$ 750,000$ USD was issued by the New York Department of Transportation (DOT) (http://files.ctctcdn.com/08b78 404201/13a45c32-5814-4869-8bb4-f2cee531dcab.pdf). This was "phase 2" of what the New York DOT called, "Biological Control of Invasive Phragmites australis." Presumably, funding for phase 1 was also made available.

\section{Conclusions}

Because of the knowledge base that has been formed over the last two decades, the ease with which research can be conducted, the global nature of the $P$. australis plant system, and the large number of active scientists currently working on this system, collaborative research is the next logical step. As $P$. australis has become a de facto model system, a group of scientists from all over the world have recently formed a collaborative Phragmites Network research group nicknamed PhragNet. PhragNet includes researchers and students from North America, South America, Europe, Asia, Australia and South Africa who are developing synergistic research approaches for global scale questions in ecology and biological invasions. As noted by Kueffer et al. (2013), "More intensive studies on particular model organisms and ecosystems are needed to improve our understanding of the full suite of interacting factors that influence invasions." We assert that $P$. australis is a strong candidate for fulfilling this need and also offers the ability to do comparative studies across different system types and genotypes in the field and in common garden studies to test invasion theory and help inform predictions for the future outcomes of global environmental change.

Acknowledgments LAM and JTC were supported by NSF research Grant 1049914 and 1050084. PP and LAM were supported by the Czech Science Foundation (Project No. 14-15414S), PP also by long-term research development project RVO 67985939 (The Czech Academy of Sciences) and Praemium Academiae award from The Czech Academy of Sciences.

\section{References}

Able KW, Hagan SM, Brown SA (2003) Mechanisms of marsh habitat alteration due to Phragmites: response of young-ofthe-year mummichog (Fundulus heteroclitus) to treatment for Phragmites removal. Estuaries 26:484-494

Achenbach L, Eller F, Nguyen LX, Brix H (2013) Differences in salinity tolerance of genetically distinct Phragmites australis clones. AoB Plants 5:plt019

Al-Garni SMS (2006) Increasing NaCl-salt tolerance of a halophytic plant Phragmites australis by mycorrhizal symbiosis. Am Eurasian J Agric Environ Sci 1:119-126

Allen WJ, Young RE, Bhattarai G, Croy JR, Meyerson LA, Cronin JT (2015) Enemy release and invasional meltdown of introduced plants and herbivores: Phragmites australis and Lipara spp. in North America. Biol Invasions 17:3419-3432

Bastlová D, Bastl M, Čižková H, Květ J (2006) Plasticity of Lythrum salicaria and Phragmites australis growth characteristics across a European geographical gradient. Hydrobiologia 570:237-242

Bhattarai GP, Cronin JT (2014) Hurricane activity and the largescale pattern of spread of an invasive plant species. PLoS One 9:e98478. doi:10.1371/journal.pone.0098478

Bhattarai GP, Meyerson LA, Anderson J, Cummings D, Allen WJ, Cronin J (in review) The biogeography of a plant invasion: genetic variation and plasticity in latitudinal clines for plant-herbivore interaction traits. Ecol Monogr

Blossey B, Nötzold R (1995) Evolution of increased competitive ability in invasive nonindigenous plants: a hypothesis. J Ecol 83:887-889

Bossdorf O, Richards CL, Pigliucci M (2008) Epigenetics for ecologists. Ecol Lett 11:106-115

Brix H (1994) Use of constructed wetlands in water pollution control: historical development, present status, and future perspectives. Water Sci Technol 30:209-224

Brix H (1999) The European research project on reed die-back and progression (EUREED). Limnologica 29:5-10

Broennimann O, Treier UA, Muller-Schärer H, Thuiller W, Peterson AT, Guisan A (2007) Evidence of climatic niche shift during biological invasion. Ecol Lett 10:701-709 
Canavan S, Wilson JRU, Visser V, Le Roux JJ, Vorontsova MS, Richardson DM (2016) The global dissemination of bamboos (Poaceae: Bambusoideae): a review. AoB plants

Caplan JS, Wheaton CN, Mozdzer TJ (2014) Belowground advantages in construction cost facilitate a cryptic plant invasion. AoB Plants. doi:10.1093/aobpla/plu020

Chambers RM, Meyerson LA, Saltonstall K (1999) Expansion of reed into tidal wetlands of North America. Aquat Bot 64:261-273

Č́žzová H, Strand JA, Lukavská J (1996) Factors associated with reed decline in a eutrophic fishpond, Rožmberk (South Bohemia, Czech Republic). Folia Geobot Phytotaxon 31:73-84

Clay K, Shearin ZRC, Bourke KA, Bickford WA, Kowalski KP (2016) Diversity of fungal endophytes in non-native Phragmites australis in the Great Lakes. Biol Invasions. doi:10.1007/s10530-016-1137-y

Clevering OA, Lissner J (1999) Taxonomy, chromosome numbers, clonal diversity and population dynamics of Phragmites australis. Aquat Bot 64:185-208

Colautti RI, Franks SJ, Hufbauer RA, Kotanen P, Torchin M, Byers JE, Pyšek P, Bossdorf O (2014) The Global Garlic Mustard Field Survey: challenges and opportunities of a unique, large-scale collaboration for invasion biology. NeoBiota 21:29-47

Crocker EV, Karp MA, Nelson EB (2015) Virulence of oomycete pathogens from Phragmites australis-invaded and noninvaded soils to seedlings of wetland plant species. Ecol Evol 5:2127-2139

Cronin JT, Bhattarai G, Allen WJ, Meyerson LA (2015) Biogeography of a plant invasion: plant-herbivore interactions. Ecology 96:1115-1127

Cronin JT, Kiviat E, Meyerson LA, Bhattarai GP, Allen WJ (2016) Biological control of invasive Phragmites will be detrimental to native Phragmites. Biol Invasions. doi:10. 1007/s10530-016-1138-x

Dibble KL, Meyerson LA (2012) Tidal flushing restores the physiological condition of fish residing in degraded salt marshes. PLoS One. doi:10.1371/journal.pone.0046161

Dibble KL, Meyerson LA (2013) The effects of plant invasion and ecosystem restoration on energy flow through salt marsh food webs. Estuaries Coasts. doi:10.1007/s12237013-9673-5

Dibble KL, Meyerson LA (2016) Detection of decreased quantities of spawning capable Fundulus heteroclitus in tidally restricted marshes relative to restored and reference sites. Biol Invasions (in review)

Dibble KL, Pooler P, Meyerson LA (2013) Impacts of plant invasions can be reversed through restoration: a regional meta-analysis of faunal communities. Biol Invasions 15:1725-1737

Douhovnikoff V, Spens A (2016) Epigenetic variation within Phragmites australis among lineages, genotypes, and ramets. Biol Invasions (in review)

Dykyjová D, Hejný S, Květ J (1973) Proposal for international comparative investigations of production by stands of reed (Phragmites communis). Folia Geobot Phytotaxon 8:435-442

Egan D (2001) A new acid test for ecological restoration. Ecol Restor 19:4
Eller F, Lambertini C, Nguyen LX, Brix H (2014) Increased invasive potential of non-native Phragmites australis: elevated $\mathrm{CO}_{2}$ and temperature alleviate salinity effects on photosynthesis and growth. Glob Change Biol 20:531-543

Farnsworth EJ, Meyerson LA (1999) Species composition and inter-annual dynamics of a freshwater tidal plant community following removal of the invasive grass, Phragmites australis. Biol Invasions 1:115-127

Gilmore MS, Wilson EH, Barrett N, Civco DL, Prisloe S, Hurd JD, Chadwick C (2008) Integrating multi-temporal spectral and structural information to map wetland vegetation in a lower Connecticut River tidal marsh. Remote Sens Environ 112:4048-4060

Gratton C, Denno RF (2006) Arthropod food web restoration following removal of an invasive wetland plant. Ecol Appl 16:622-631

Guo W, Lambertini C, Li X-Z, Meyerson LA, Brix H (2013) Invasion of Old World Phragmites australis in the New World: precipitation and human influences redesign the invasive niche. Glob Change Biol 19:3406-3422

Harley JL, Harley EL (1987) A checklist of mycorrhiza in the British flora-addenda, errata and index. New Phytol 107:741-749

Haslam S (1971a) Community regulation in Phragmites communis Trin. I. Mono dominant stands. J Ecol 59:65-73

Haslam S (1971b) Community regulation in Phragmites communis Trin. II. Mixed stands. J Ecol 59:75-88

Hazelton ELG, Mozdzer TJ, Burdick DM, Kettenring KM, Whigham DF (2014) Phragmites australis management in the United States: 40 years of methods and outcomes. AoB Plants 6:plu001

Holdredge C, Bertness MD, von Wettberg E, Silliman BR (2010) Nutrient enrichment enhances hidden differences in phenotype to drive a cryptic plant invasion. Oikos 119:1776-1784

Holt RD, Lawton JH (1994) The ecological consequences of shared natural enemies. Annu Rev Ecol Syst 25:495-520

Hughes AR, Schenck FR, Bloomberg J, Hanley TC, Tarik DF, Gouhier C, Beighley RE, Kimbro DL (2016) Biogeographic gradients in ecosystem processes of the invasive ecosystem engineer Phragmites australis. Biol Invasions (in revision)

Hulme P, Pyšek P, Jarošik V, Pergl J, Schaffner U, Vila M (2013) Bias and error in understanding invasions and impacts. Trends Ecol Evol 28:212-218

Hunter KL, Fox DA, Brown LM, Able KW (2006) Responses of resident marsh fishes to stages of Phragmites australis invasion in three mid Atlantic estuaries. Estuaries Coasts 29:487-498

Isac M, Preda S, Marcu M (1998) Aphid species-vectors of plum pox virus. Acta Virol 42:233-234

Kiviat E (2013) Ecosystem services of Phragmites in North America with emphasis on habitat functions. AoB plants 5:plt008

Kowalski KP, Bacon C, Bickford W, Braun H, Clay K, LeducLapierre M, Lillard E, McCormick MK, Nelson E, Torres M, White J, Wilcox DA (2015) Advancing the science of microbial symbiosis to support invasive species management: a case study on Phragmites in the Great Lakes. Front Microbiol 6:95. doi:10.3389/fmicb.2015.00095 
Kueffer C, Pyšek P, Richardson DM (2013) Integrative invasion science: model systems, multi-site studies, focused metaanalysis, and invasion syndromes. New Phytol 200:615-633

Lambert A, Dudley T, Saltonstall K (2010) Ecology and Impacts of the large-statured invasive grasses Arundo donax and Phragmites australis in North America. Invasive Plant Sci Manag 3:489-494

Lambert A, Saltonstall K, Long R, Dudley T (2016) Biogeography of Phragmites lineages in the southwestern United States. Biol Invasions (in review)

Lambertini C, Gustafsson MHG, Frydenberg J, Lissner J, Speranza M, Brix H (2006) A phylogeographic study of the cosmopolitan genus Phragmites (Poaceae) based on AFLPs. Plant Syst Evol 258:161-182

Lambertini C, Mendelssohn IA, Gustafsson MHG, Olese B, Riis T, Sorrell BK, Brix H (2012) Tracing the origin of Gulf Coast Phragmites (Poaceae): a story of long-distance dispersal and hybridization. Am J Bot 99:538-551

Lozier JD, Roderick GK, Mills NJ (2009) Tracing the invasion history of mealy plum aphid, Hyalopterus pruni (Hemiptera: Aphididae), in North America: a population genetics approach. Biol Invasions 11:299-314

Marks M, Lapin B, Randall J (1994) Phragmites australis ( $P$. communis): threats, management and monitoring. Nat Areas J 14(4):285-294

Martin L, Blossey B (2013) The runaway weed: costs and failures of Phragmites australis management in the USA. Estuaries Coasts 36:626-632

Meyerson LA, Cronin JT (2013) Evidence for multiple introductions of Phragmites australis to North America: detection of a new non-native haplotype. Biol Invasions 15:2605-2608

Meyerson LA, Chambers RM, Vogt KA (1999) The effects of Phragmites removal on nutrient pools in a freshwater tidal marsh ecosystem. Biol Invasions 1:129-136

Meyerson LA, Vogt KA, Chambers RM (2000a) Linking the success of Phragmites to the alteration of ecosystem nutrient cycles. In: Weinstein MP, Kreeger DA (eds) Concepts and controversies in tidal marsh ecology. Springer, Netherlands, pp 827-844

Meyerson LA, Saltonstall K, Windham L, Kiviat E, Findlay S (2000b) A comparison of Phragmites australis in freshwater and brackish marsh environments in North America. Wetlands Ecol Manag 8:89-103

Meyerson LA, Saltonstall K, Chambers RM (2009) Phragmites australis in eastern North America: a historical and ecological perspective. In: Silliman BR, Grosholz ED, Bertness MD (eds) Human impacts on salt marshes: a global perspective. University of California Press, Berkeley, pp 57-82

Meyerson LA, Lambert AM, Saltonstall K (2010a) A tale of three lineages: expansion of common reed (Phragmites australis) in the U.S. Southwest and Gulf Coast. Invasive Plant Sci Manag 3:515-520

Meyerson LA, Viola DV, Brown RN (2010b) Hybridization of invasive Phragmites australis with a native subspecies in North America. Biol Invasions 12:103-111

Meyerson LA, Lambertini C, McCormick MK, Whigham DF (2012) Hybridization of common reed in North America? The answer is blowing in the wind. AoB plants 2012:pls022
Meyerson LA, Pergl J, Pyšek P (2014) Making waves about spreading weeds. Science 344:1236

Meyerson LA, Cronin JT, Bhattarai GP, Brix H, Lambertini C, Lučanová M, Rinehart S, Suda J, Pyšek P (2016) Ploidy level and nuclear genome size modify the expression of plant traits and response to herbivory in Phragmites australis. Biol Invasions (in revision)

Mozdzer TJ, Megonigal JP (2013) Increased methane emissions by an introduced Phragmites australis lineage under global change. Wetlands 33:609-615

Mozdzer TJ, Brisson J, Hazelton E (2013) Physiological ecology and functional traits of North American native and Eurasian introduced Phragmites australis lineages. AoB Plants 5:plt048

Nelson EB, Karp MA (2013) Soil pathogen communities associated with native and non-native Phragmites australis populations in freshwater wetlands. Ecol Evol 3:5254-5267

Oliveira RS, Dodd JC, Castro PML (2001) The mycorrhizal status of Phragmites australis in several polluted soils and sediments of an industrialised region of Northern Portugal. Mycorrhiza 10:241-247

Packer J, Meyerson LA, Skálová H, Haslam S, Pyšek P, Kueffer C (2016) Biological Flora of the British Isles: Phragmites australis. J Ecol (in review)

Parker JD, Torchin ME, Hufbauer RA, Lemoine NP, Alba C, Blumenthal DM, Bossdorf O, Byers JE, Dunn AM, Heckman RW, Hejda M, Jarošík V, Kanarek AR, Martin LB, Perkins SE, Pyšek P, Schierenbeck K, Schlöder C, van Klinken R, Vaughn KJ, Williams W, Wolfe LM (2013) Do invasive species perform better in their new ranges? Ecology 94:985-994

Pellegrin D, Hauber DP (1999) Isozyme variation among populations of the clonal species, Phragmites australis (Cav.) Trin. ex Steudel. Aquat Bot 63:241-259

Pimentel D, Zuniga R, Morrison D (2005) Update on the environmental and economic costs associated with alien-invasive species in the United States. Ecol Econ 52:273-288

Prentis PJ, Wilson JRU, Dormontt EE, Richardson DM, Lowe AJ (2013) Adaptive evolution in invasive species. Trends Plant Sci 13:288-294

Pyšek P, Richardson DM, Pergl J, Jarošík V, Sixtová Z, Weber E (2008) Geographical and taxonomic biases in invasion ecology. Trends Ecol Evol 23:237-244

Saltonstall K (2002) Cryptic invasion by a non-native genotype of the common reed, Phragmites australis, into North America. Proc Natl Acad Sci 99:2445-2449

Saltonstall K (2003a) Microsatellite variation within and among North American lineages of Phragmites australis. Mol Ecol 12:1689-1702

Saltonstall K (2003b) A rapid method for identifying the origin of North American Phragmites populations using RFLP analysis. Wetlands 23:1043-1047

Saltonstall K, Peterson PM, Soreng RJ (2004) Recognition of Phragmites australis subsp. americanus (Poaceae: Arundinoideae) in North America: evidence from morphological and genetic analyses. SIDA 21:683-692

Saltonstall K, Glennon K, Burnett A, Hunter RB, Hunter KL (2007) Comparison of morphological variation indicative of ploidy level in Phragmites australis (Poaceae) from eastern North America. Rhodora 109:415-429 
Saltonstall K, Castillo H, Blossey B (2014) Confirmed field hybridization of native and introduced Phragmites australis (Poaceae) in North America. Am J Bot 101:211-215

Saltonstall K, Lambert A, Rice N (2016) What happens in Vegas, better stay in Vegas: Phragmites australis hybrids in the Las Vegas Wash. Biol Invasions (in revision)

Simberloff D, Von Holle B (1999) Positive interactions of nonindigenous species: invasional meltdown? Biol Invasions 1:21-32

Soares MA, Li H-Y, Kowalski KP, Bergen M, Torres MS, White JF (2016) Evaluation of the functional roles of fungal endophytes of Phragmites australis from high saline and low saline habitats. Biol Invasions (this issue)

Suda J, Meyerson LA, Pyšek P, Leitch I (2014) The hidden side of plant invasions: the role of genome size. New Phytol 205:994-1007

Swearingen J, Saltonstall K (2010) Phragmites field guide: distinguishing native and exotic forms of common reed (Phragmites australis) in the United States. Weeds Gone Wild, Plant Conservation Alliance (http://www.nps.gov/ plants/alien/fact/pdf/phau1-powerpoint.pdf)

Tscharntke T (1992) Cascade effects among four trophic levels: bird predation on galls affects density-dependent parasitism. Ecology 73:1689-1698
Weber E (2003) Invasive plant species of the world: a reference guide to environmental weeds. CAB International Publishing, Wallingford

Wu J, Ma F, Wang L, Yang J, Huang X, An G, Liu S (2014) Seedling performance of Phragmites australis (Cav.) Trin ex. Steudel in the presence of arbuscular mycorrhizal fungi. J Appl Microbiol 116:1593-1606

Wu CA, Murray LA, Heffernan KE (2015) Evidence for natural hybridization between native and introduced lineages of Phragmites australis (Poaceae) in the Chesapeake Bay watershed. Am J Bot 102:805-812

Yarwood S, Baldwin A, Mateu MG, Buyer J (2016) Archaeal rhizosphere communities differ between the native and invasive lineages of the wetland plant Phragmites australis (common reed) in a Chesapeake Bay subestuary. Biol Invasions. doi:10.1007/s10530-016-1144-Z

Zhang Q, Sun Q, Koide RT, Peng Z, Zhou J, Gu X, Gao W, Yu M (2014) Arbuscular mycorrhizal fungal mediation of plant-plant interactions in a marshland plant community. Sci World J. doi:10.1155/2014/923610 